\title{
Reproductive biology of Coral Catshark Atelomycterus marmoratus (Anonymous [Bennett], 1830) in Seribu Islands, Indonesia
}

\author{
SELVIA OKTAVIYANI", WANWAN KURNIAWAN, FAHMI \\ Research Center for Oceanography, Indonesian Institute of Sciences. East Ancol, North Jakarta 14430, Jakarta, Indonesia. \\ Tel./Fax. +62-216-4713850, `email: selvia.oktaviyani@gmail.com.
}

Manuscript received: 21 April 2019. Revision accepted: 16 July 2019.

\begin{abstract}
Oktaviyani S, Kurniawan W, Fahmi. 2019. Reproductive biology of Coral Catshark Atelomycterus marmoratus (Anonymous [Bennett], 1830) in Seribu Islands, Indonesia. Biodiversitas 20: 2166-2176. This study provides information on the reproductive biology of the coral catshark caught in the waters around Seribu Islands, Indonesia. A total of 257 coral catsharks were collected from February 2017 to January 2018. The total length of coral catshark ranged from 170 to $585 \mathrm{~mm}$ for females and $255-575 \mathrm{~mm}$ for males. The total mass of females ranged from 85 to $640 \mathrm{~g}$ and males from 100 to $620 \mathrm{~g}$ The sex ratio between females and males was 0.45 , and it was not significantly different from the expected 1:1 ratio. The growth pattern of coral catsharks in Seribu Island was negatively allometric, and mature sharks dominated the population. The mean size at first maturity was estimated to be $557 \mathrm{~mm}$ for females and $514 \mathrm{~mm}$ for males, based on the relationship between the proportion between maturity stage and total length. The ovulation season was estimated occur from October to March, whereas September to April was mating season based on monthly variations of gonadosomatic index (GSI) values and the occurrence of egg cases in the uterus.
\end{abstract}

Keywords: Coral catshark, maturity, reproduction, Seribu Islands

\section{INTRODUCTION}

The coral catshark, Atelomycterus marmoratus, is a small shark species of the Family Scyliorhinidae. Scyliorhinidae is the largest shark family with more than 150 species. This group of sharks generally has a maximum total length less than $1 \mathrm{~m}$, live in tropic and temperate latitude area from shallow coastal waters to $2.000 \mathrm{~m}$ (Compagno 1988; Compagno and Niem 1998; Compagno et al. 2005). The coral catshark has a specific color pattern on its body, its dorsal side is greyish to brownish with white spots outlined by large black spots, bars, and lines from head to tail (Compagno and Niem 1998; White et al. 2006). This shark is oviparous species (egg-laying) and can reach its maximum body length up to $700 \mathrm{~mm}$ (Compagno 1984; White et al. 2006).

The coral catshark is found on coral reefs and inhabits crevices and holes on reefs. They distribute in the IndoWest Pacific including Pakistan, India, Thailand, Malaysia, Indonesia, and New Guinea, and also in northern regions, from The Philipinnes, Viet Nam, China and Taiwan (Compagno and Niem 1998). From three species of catsharks of the Genus Atelomycterus that occur in Indonesia waters, A. marmoratus or coral catshark is the most common one (White et al. 2005; White et al. 2006; Fahmi and White 2015). It occurs in almost all coral reef waters from western to eastern Indonesia and often caught as bycatch or minor catch in artisanal fisheries in Indonesia. This species is utilized for food (fresh and dried salted), processed for fishmeal, and also commonly keep in the aquarium as an ornamental fish (Compagno and Niem 1998; Fahmi 2016).

Even though the coral catshark is a common species, but little known about its biological information in its region, especially in Indonesia. There are only few studies related to the coral catshark, such as a study on the egg capsules of A. marmoratus (Bor et al. 2003), a part of aspects of the biology of carcharhiniform shark in Indonesia (White 2007) and a breeding study of this species (Atelomycterus marmoratus) in the aquarium (Hövel et al. 2010). Based on the data of the red list of endangered species from International Union for Conservation of Nature and Natural Resources (IUCN), the status of coral catshark is near threatened (NT), but it needs to be updated because the evaluation was more than ten years ago (White 2003). Therefore, this study was conducted to fill the information gap of coral catshark biology. The focus of our study was to evaluate the reproductive parameters of coral catshark in Seribu Islands, Indonesia.

\section{MATERIALS AND METHODS}

\section{Study area}

This study was conducted through a monthly sampling at Tanjung Pasir fish landing in Tangerang, Indonesia, from February 2017 to January 2018. All specimens were caught by longliners or trap net fishers operated daily in the waters of Seribu Islands, Indonesia (Figure 1 and Figure 2). 


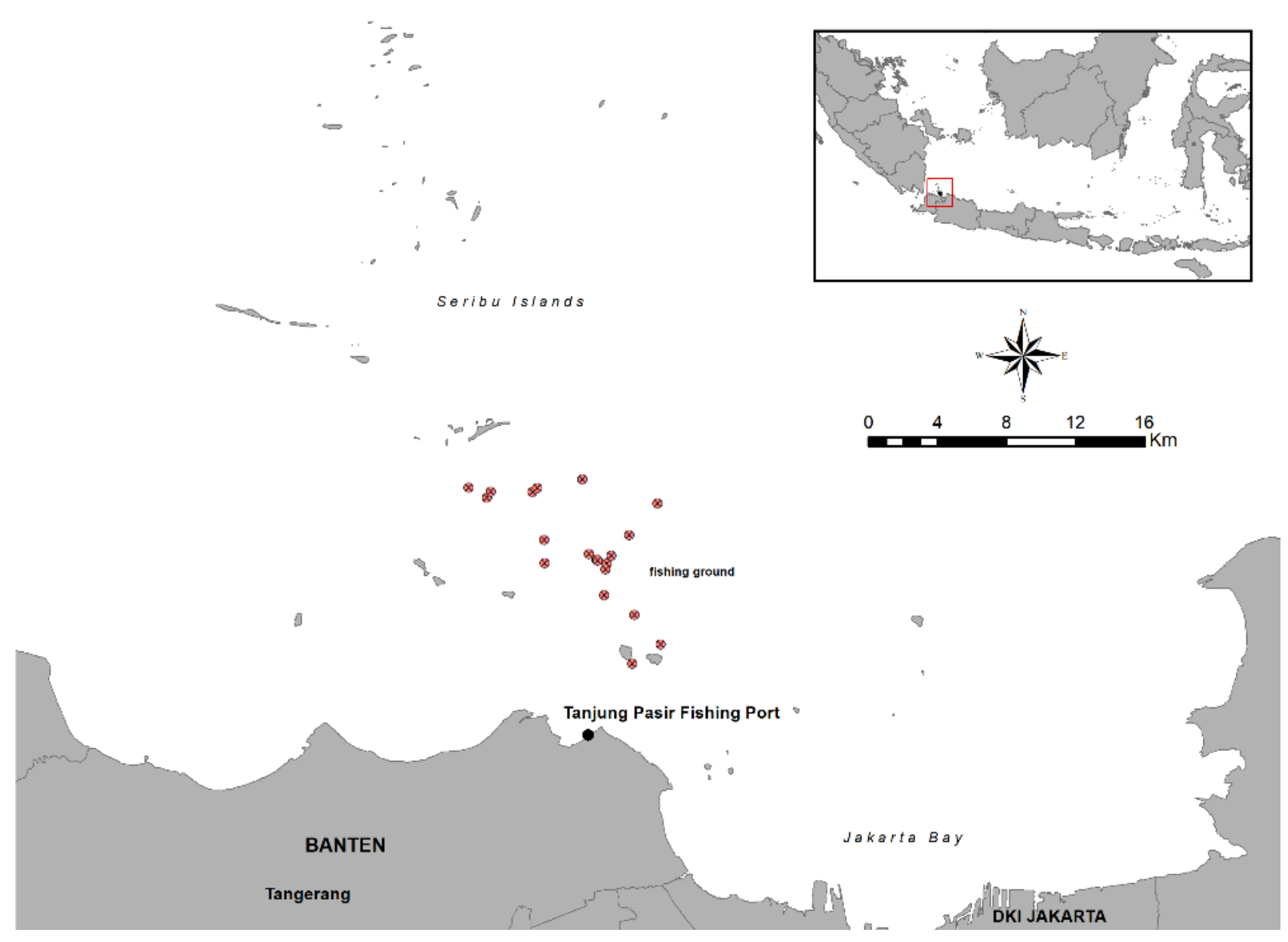

Figure 1. Sampling site and fishing grounds $(\bullet)$ of coral catsharks in the waters of Seribu Islands, Indonesia

\section{Sample collection}

The data collected in this study, including sex determination, measurements of total body length (TL), and body mass $(\mathrm{W})$. The total length was measured from the tip of the snout to the end of caudal fin using a $1 \mathrm{~m}$ ruler. Determination of coral catshark sex was done visually, based on the presence or absence of claspers as male reproduction organ. Clasper length was measured from the outer margin length of the left clasper using a digital caliper. The total length and clasper length were measured to the nearest millimeter, whereas the weighing was done to the nearest gram. Reproductive organs were analyzed and measured to record the maturity stage, the condition of uteri, testes, and ovary mass, the maximum ovarian egg diameter (MOD), and counting the number of egg cases.

Sexual maturity of females and male referred to criteria by Pratt (1988), Stehmann (2002) and Chen and Liu (2006). The determination for sexual maturity of females was based on the ovary condition, egg, and shell gland, with the following criteria (Figure 3): (i) Immature, juvenile: ovaries small, thin, their internal structure gelatinous or granulated. No oocytes differentiated or extremely small and often not visible to the naked eye, granular. Oviducts (uteri) narrow and thread-like; (ii) Maturing, adolescent: ovaries somewhat enlarged, walls more transparent. Oocytes becoming differentiated to various small sizes. Uteri thickening and largely as stage 1 but may become widened posteriorly; and (iii) Mature, adult: ovaries large and right. Oocytes enlarged, with some being very large. Uteri enlarged and widening over nearly their entire length.

Male's maturity stages were based on changes and structure of male external genital or claspers, with the following conditions (Figure 4): (i) Immature, juvenile: claspers undeveloped as small, not calcified and very soft as well as less than the pelvic fins length. Testes small, sperm ducts straight and thread-like; (ii) Maturing, adolescent: clasper becoming extended, approaching tips of posterior pelvic lobes, as long as or a bit longer than posterior pelvic lobes, still soft, flexible, and the clasper was not fully calcified. Testes enlarged, sperm ducts eventually beginning to meander (coil); and (iii) Mature, adult: claspers full length and calcified, longer than the pelvic fins. Testes greatly enlarged, sperm ducts meandering over almost their entire length and tightly filled with sperm. 


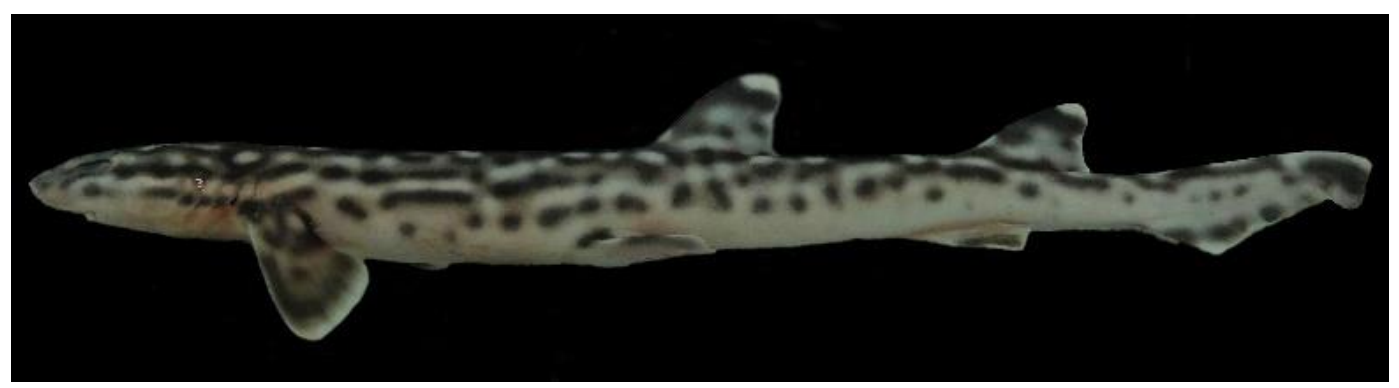

Figure 2. Coral catshark, Atelomycterus marmoratus in the waters of Seribu Islands, Indonesia

\section{Data analysis}

The relationship between the total length and body mass of fish was expressed by equation:

$$
\mathrm{W}=\mathrm{aL}^{\mathrm{b}}(\text { Ricker 1973) }
$$

\section{Where:}

W : Body mass of fish

L : Total length of fish

a : Constant (intercept)

b : The length exponent (slope).

The intercept and slope values were obtained from a linear regression of the length and mass of fish through the $\log$ transformation. The value of " $b$ " provides information on the condition and growth pattern of fish. Fish were said had isometric growth when length increases in equal proportions with body length, however, when the length or mass more dominant so the fish had allometric growth. The length exponent (slope/b) for isometric growth is " 3 ", whereas if value significantly greater or lesser than " 3 " indicated allometric growth. In order to confirm whether " $b$ " values significantly different from the isometric value $(b=3)$, then was tested by t-test with evident level $5 \%$ or $\alpha=0.05$, where $b<3$ negatively allometric and $b>$ three positively allometric (Morey et al. 2003).

Sex ratio showed the proportion between the number of females and total specimens. Thus, it was continued by the Chi-square test to evaluate homogeneity from the sex ratio for each month sampling (Gay 1996).

The size at sexual maturity for males was determined throughout the result of clasper length and testis mass plots against total length because most of Elasmobranchii species experienced a rapid increase in clasper size when males reach sexual maturity while the size at sexual maturity of females was determined by plotting the mass of ovary against the total length (Chen and Liu 2006).

The mean size at first maturity was defined as the length when $50 \%$ from all specimens, both males and females were mature. The logistic model $\mathrm{Y}=1 /\left[1+\mathrm{e}^{(\mathrm{a}+\mathrm{bTL})}\right]$ was used to describe the relationship between the proportion of mature fish (Y) in each length class range and total length for males and females (King 1995). Subsequently, the mean size at first maturity was obtained by substituting $\mathrm{Y}=0.5$ in the equation.
The ovaluation season was estimated thru values of Gonadosomatic Index (GSI) of mature specimens, which was obtained from the equation $G S I=\frac{W g}{W} \times 10^{2}$, where $\mathrm{Wg}$ is gonad mass (ovary and testes), $\mathrm{W}$ is the body mass. Maximum ova diameter (MOD) and the presence, as well as the size of female egg cases, was used to further verify the time of the female reproductive cycle.

\section{RESULTS AND DISCUSSION}

\section{Results}

During the study, a total of 257 coral catsharks were collected, consisting of 116 females and 141 males. The total length ranged from 170 to $585 \mathrm{~mm}$ for females and from 255 to 575 for males (Figure 5). The mass of females ranged from 85 to $640 \mathrm{~g}$ and males from 100 to $620 \mathrm{~g}$.

According to Figure 5, there are two groups or cohorts, i.e., small group (175-258 $\mathrm{mm} \mathrm{TL})$ and large size group (301-594 mm TL). Males and females of coral catshark mostly caught in interval length between 469-510 mm TL. The average length for all specimens is $474,32 \pm 55,12$.

In general, the sex ratio between females and males of the total specimens was 0.45 . The Chi-square test $(\alpha=0.05)$ result showed that the proportion between the number of males and females was not significantly different or in equal condition. The monthly sex ratios showed significant differences only in April and September (Table 1).

The length and mass relationships of females and males were $\mathrm{W}=0,00008 \mathrm{~L}^{2,49301}$ and $\mathrm{W}=0,00001 \mathrm{~L}^{2,80881}$, respectively (Figure 6). The t-test analysis against "b" values showed that females and males had negatively allometric growth pattern. It means that the length growth was faster than the mass. This relationship is suitable to the morphological character of coral catsharks which are having slender and elongate to moderately stout bodies.

From 116 females, 77 individuals or $66 \%$ were mature indicating by large ovaries, oocytes, and uteri. Meanwhile, $16 \%$ of females were maturing, and $18 \%$ were immature. Juvenile females have small ovaries, thin, no oocytes, and narrow oviducts. The monthly proportion of maturity stage of females shows some fluctuations throughout the year (Figure 7). 

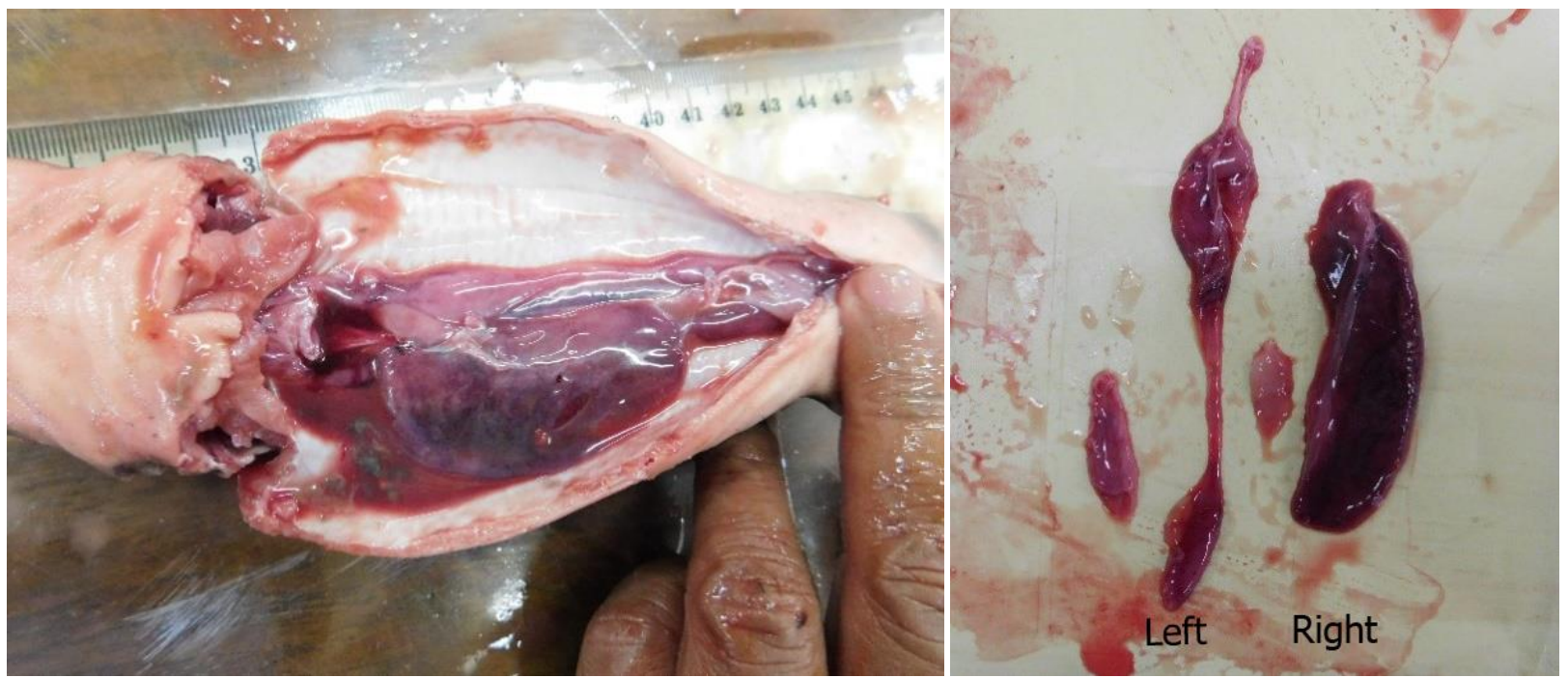

A
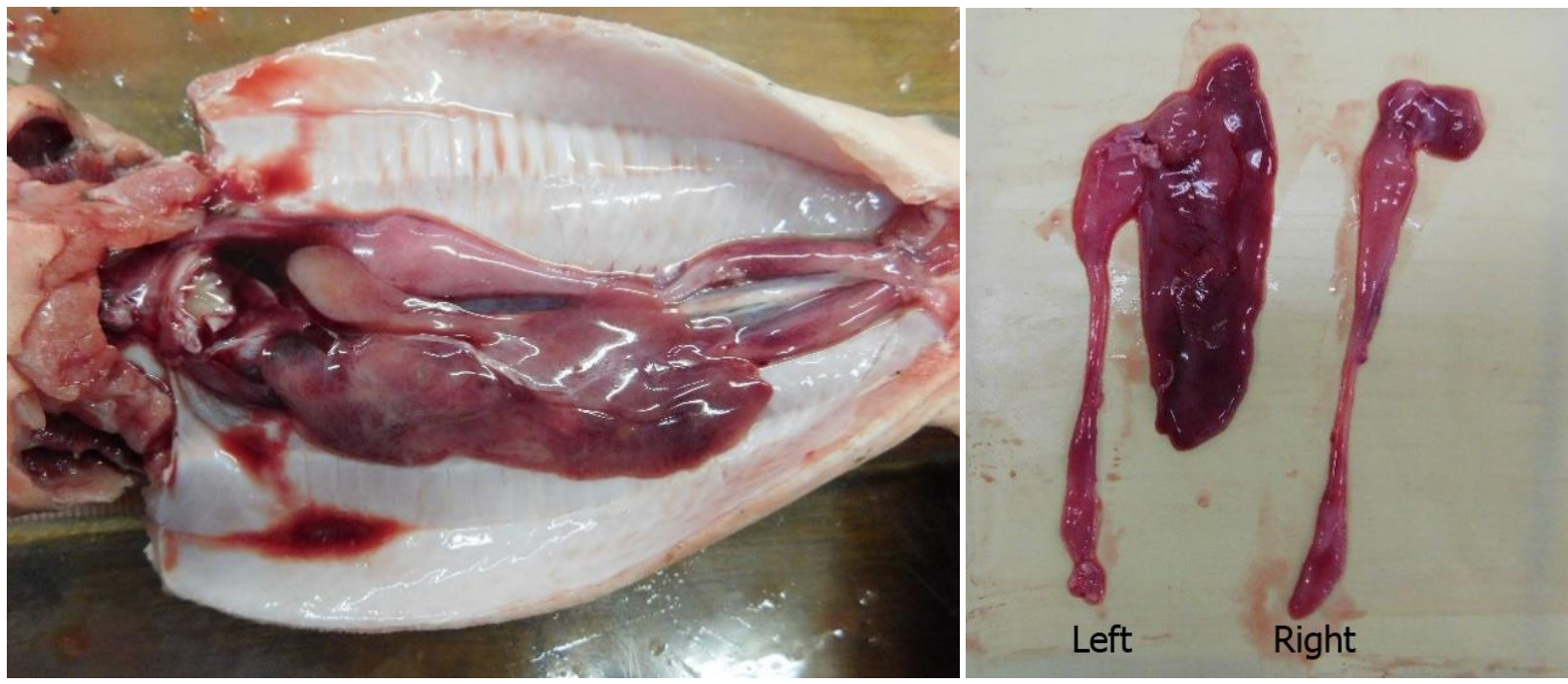

B
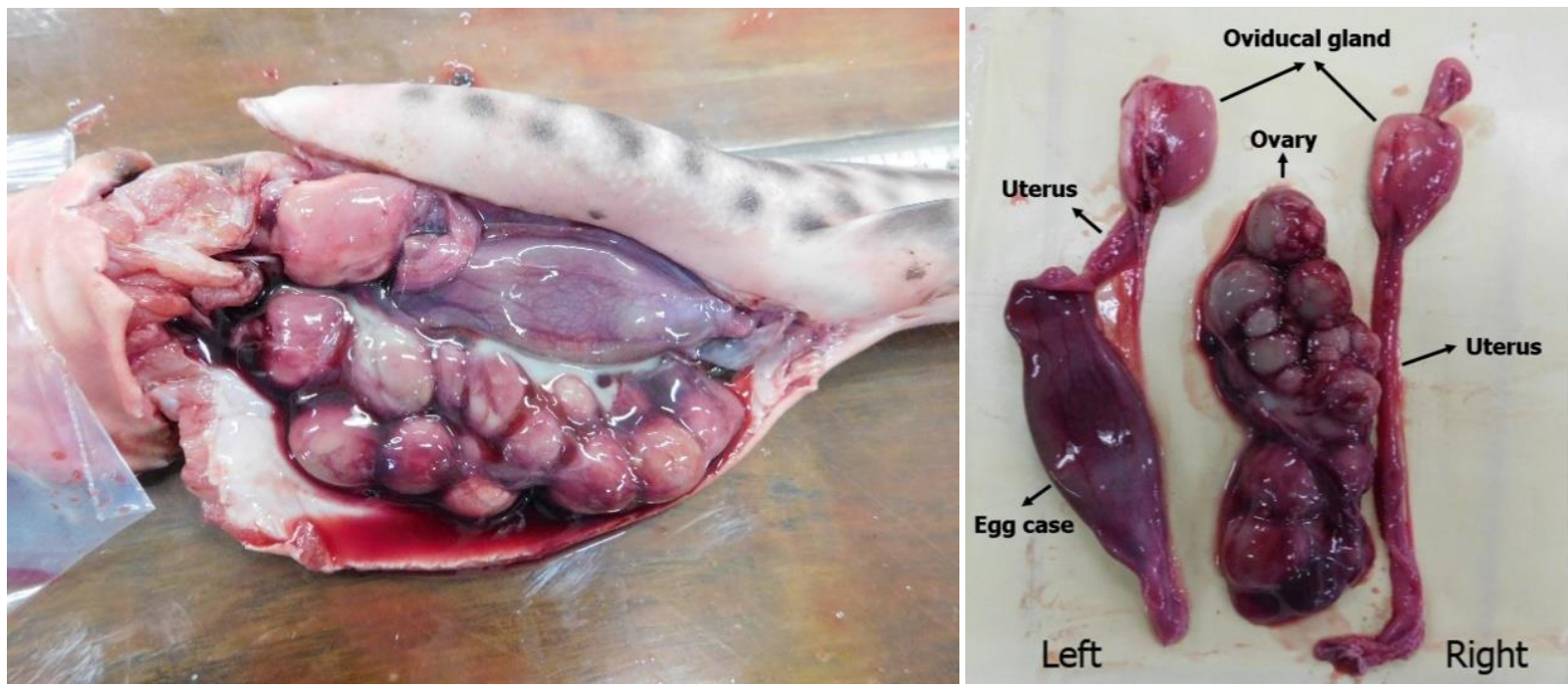

C

Figure 3. Female's maturity stage of coral catsharks in the waters of Seribu Islands, Indonesia. A. Immature's female, B. Maturing's female, C. Mature's female 

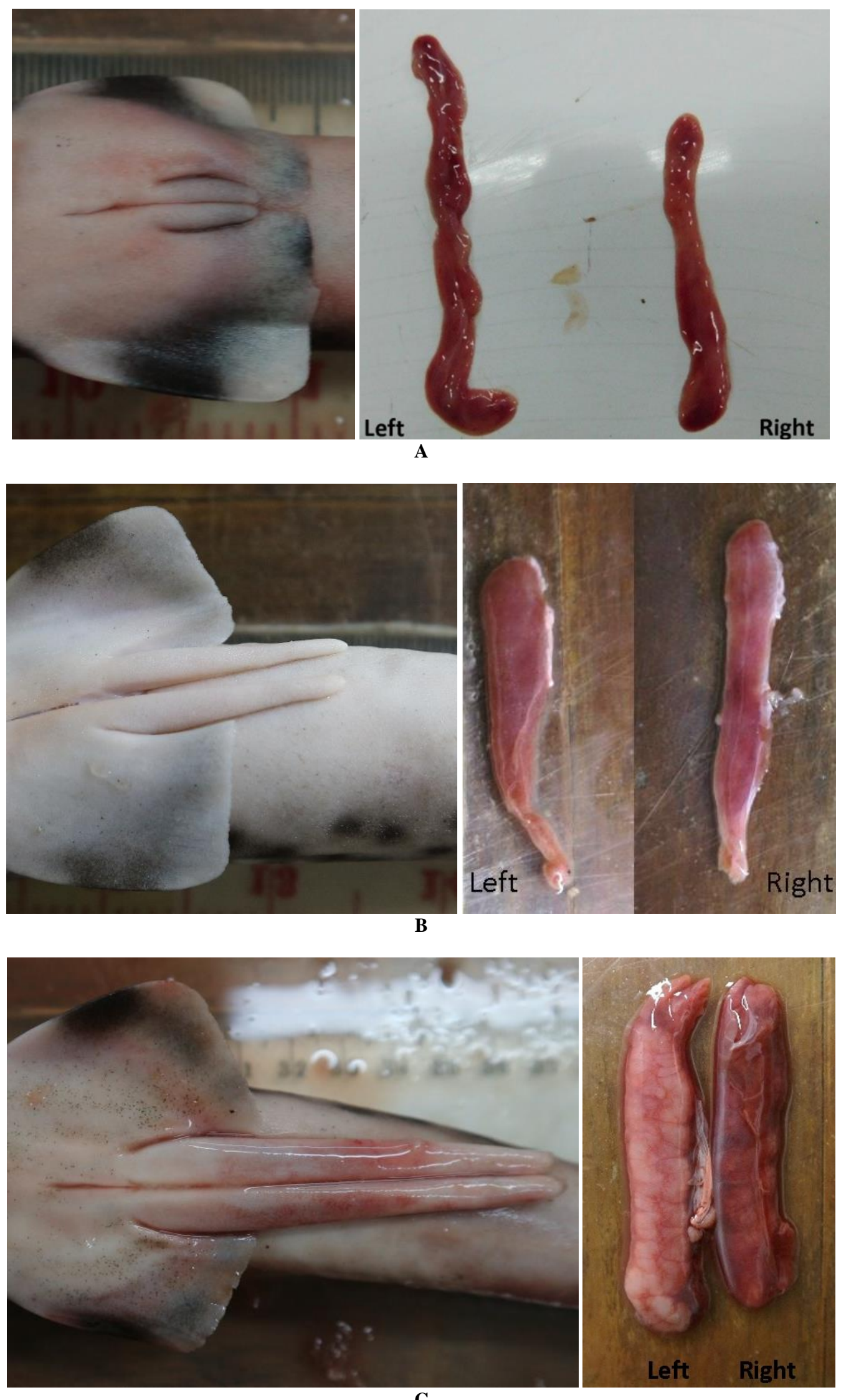

C

Figure 4. Male's maturity stage of coral catsharks in the waters of Seribu Islands, Indonesia. A. Immature's clasper and testes, B. Maturing's clasper and testes, C. Mature's clasper and testes 
Table 1. Total specimens of Atelomycterus marmoratus in the waters of Seribu Islands, Indonesia

\begin{tabular}{|c|c|c|c|c|c|c|}
\hline \multirow{2}{*}{ Month } & \multicolumn{2}{|r|}{ Males } & \multicolumn{2}{|r|}{ Females } & \multirow{2}{*}{ Total } & \multirow{2}{*}{ Sex ratio } \\
\hline & $\mathbf{n}$ & Total length range (mm) & $\mathbf{n}$ & Total length range (mm) & & \\
\hline February'17 & 14 & $350-517$ & 11 & $175-585$ & 25 & 0.44 \\
\hline March & 22 & $374-520$ & 17 & $336-525$ & 39 & 0.44 \\
\hline April & 17 & $325-570$ & 7 & $470-543$ & 24 & $0.29 *$ \\
\hline May & 4 & $524-574$ & 8 & $486-556$ & 12 & 0.67 \\
\hline June & 13 & $343-575$ & 6 & $307-510$ & 19 & 0.32 \\
\hline July & 9 & $413-530$ & 9 & $393-548$ & 18 & 0.50 \\
\hline August & 4 & $494-535$ & 4 & $487-550$ & 8 & 0.50 \\
\hline September & 17 & $443-505$ & 4 & $354-505$ & 21 & $0.19 *$ \\
\hline October & 9 & $255-520$ & 14 & $381-550$ & 23 & 0.61 \\
\hline November & 14 & $410-506$ & 10 & $410-535$ & 24 & 0.42 \\
\hline December & 9 & $455-525$ & 9 & $403-530$ & 18 & 0.50 \\
\hline Januari'18 & 9 & $360-555$ & 17 & $380-568$ & 26 & 0.65 \\
\hline
\end{tabular}

Note: *Significant at the $5 \%$ level

Immature females ranged from 175 to $472 \mathrm{~mm} \mathrm{TL}$, which were featured by small ovaries (0.1-3.9 g), thin, no oocytes differentiated or extremely small and often not visible to the naked eye, uteri narrow and thread-like. On the other hand, mature females had a length from 436 to $530 \mathrm{~mm}$ TL, and medium ovary mass (1.6-30.0 g). Mature females were discovered at size between 440 and $585 \mathrm{~mm}$ TL (Figure 8), with relatively large ovary (10.3-35.5 g). From there, we estimate the size at maturity for female coral catsharks in our study area was between 440 and 530 $\mathrm{mm}$ TL. Based on visual observation, enlarged oocytes were found with some of them being very large. The maximum ova diameter (MOD) were ranged between 15 and $26 \mathrm{~mm}$, with total MOD was between 5 and 15 eggs. The egg cases of coral catshark were small; its length ranged from 63 to $93 \mathrm{~mm}$ from the anterior to the posterior margin. The shape of egg case shaped elongate, smooth and notched like has two waists, with dark brown in color. The egg case width was about $25-45 \%$ of its length, and the height was $2-12 \%$ of its length. The egg cases were found in mature females, mostly in March and September.

The monthly proportion of maturity stage of males shows some fluctuations throughout the year (Figure 10). The curve logistic for mature females was estimated throughout the equation $\mathrm{Y}=1 /\left[1+\mathrm{e}^{(9,278-0,017 \mathrm{TL})}\right]$. Based on the equation, the mean size at first maturity for females was estimated at $557 \mathrm{~mm}$ TL (Figure 9).

From 141 males, $86 \%$ or 121 individuals were mature indicating by the long and fully calcified claspers, longer than their pelvic fins. On the other hand, only $2.8 \%$ of males were maturing, and $11.3 \%$ were immature. The monthly proportion of maturity stage of males shows some fluctuations throughout the year (Figure 10).

The relationship between clasper length and the total length for males showed a sigmoid curve. The increase of the clasper length followed the increase in the total length. The development of the clasper length was slower in the substitution process from immature to mature stages. The clasper size reached the maximum length at a certain size when males in the mature level (Figure 11).
The body size of immature males ranged from 255 to $442 \mathrm{~mm}$ TL (Figure 11). The clasper condition of those individuals at this stage were still undeveloped, small, not calcified, and the clasper length was shorter than the pelvic fin inner margin length. The length of the clasper at this stage varied from 5.7 to $29.8 \mathrm{~mm}$. The testis mass of immature males ranged from 0.2 to $1.7 \mathrm{~g}$, with the increase of the testis mass was slower than the increase of the total length (Figure 12). Based on the visual observation, the sperm ducts were straight and thread-like.

Clasper length of maturing males ranged from 30,4$49,8 \mathrm{~mm}$ with claspers condition were not fully calcified. The clasper length varied from 30.4 to $49.8 \mathrm{~mm}$, and their testes were relatively larger than immature individuals $(0.8$ $1.5 \mathrm{~g}$ ). The growth of the clasper was relatively fast comparing to the growth of the body length. At this stage, males have a sexual transition to be mature individuals that were signed by the calcification process in their claspers. The smallest mature male recorded during the study was at $398 \mathrm{~mm}$ TL. In the mature stage, all claspers had fully calcified, and the length was larger than immature and maturing individuals $(43,3-69,0 \mathrm{~mm})$, as well as having larger testes (testes mass are between 1.1 and $9.2 \mathrm{~g}$ ).

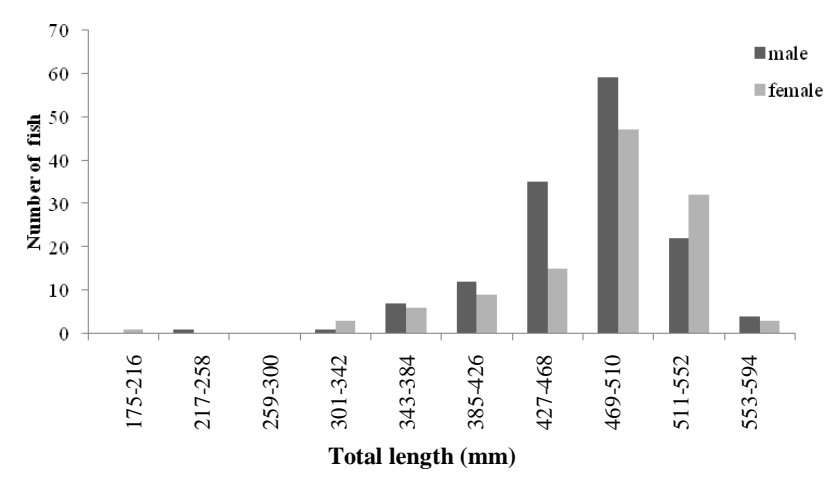

Figure 5. Length frequency distribution of Atelomycterus marmoratus in the waters of Seribu Islands, Indonesia 

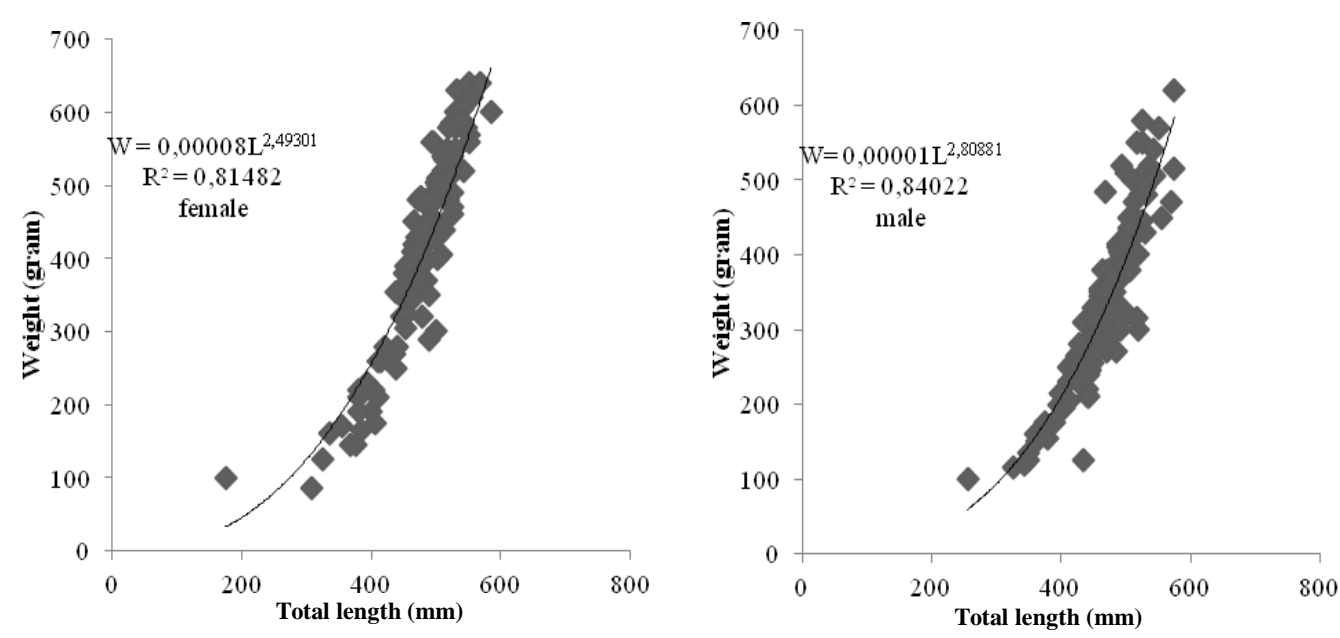

Figure 6. Length- body mass relationships for female (left) and male (right) Atelomycterus marmoratus in the waters of Seribu Islands, Indonesia

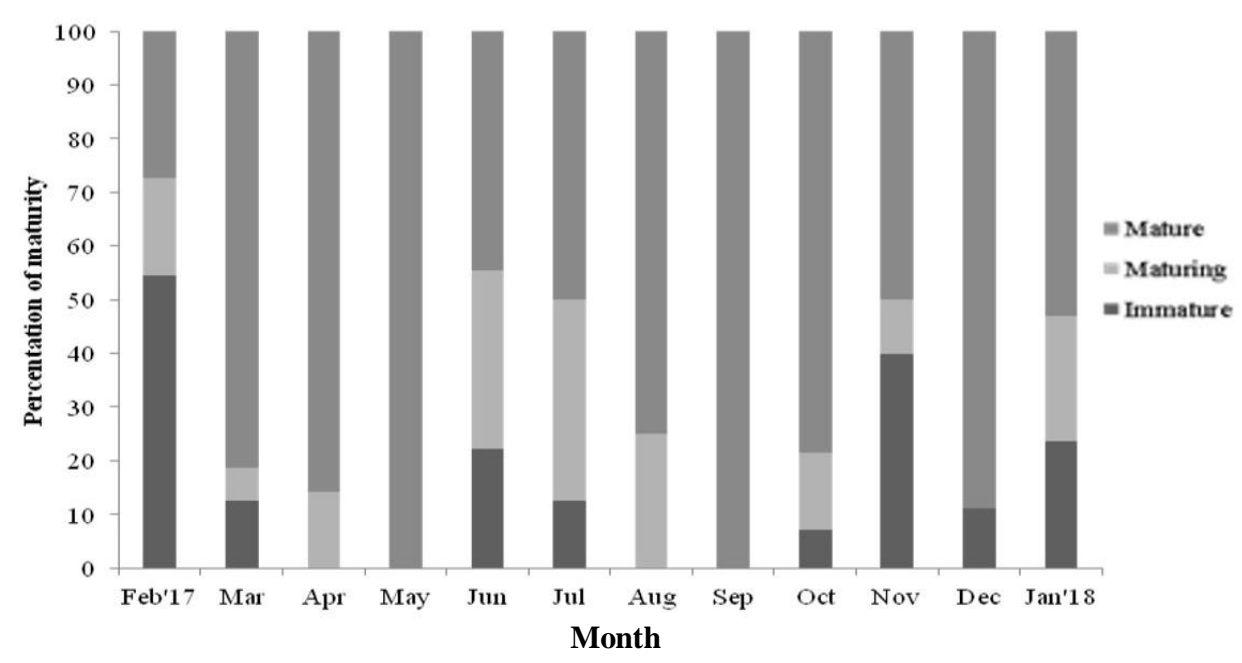

Figure 7. Percentage of maturity for female Atelomycterus marmoratus in the waters of Seribu Islands, Indonesia

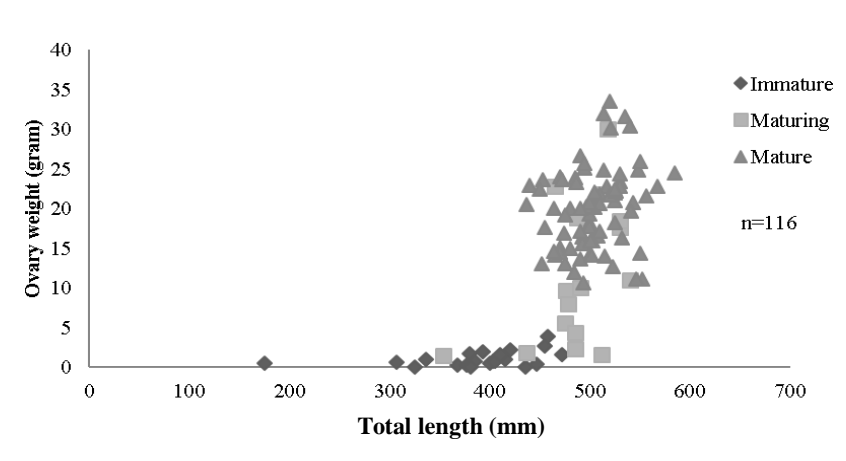

Figure 8. Relationship between total length and ovary mass for female Atelomycterus marmoratus in the waters of Seribu Islands, Indonesia

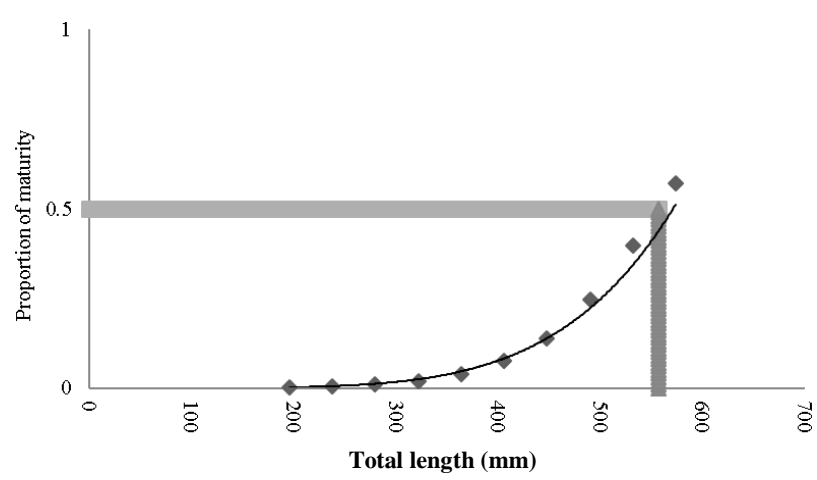

Figure 9. Relationship between the proportion of maturity and total length for female Atelomycterus marmoratus in the waters of Seribu Islands, Indonesia 


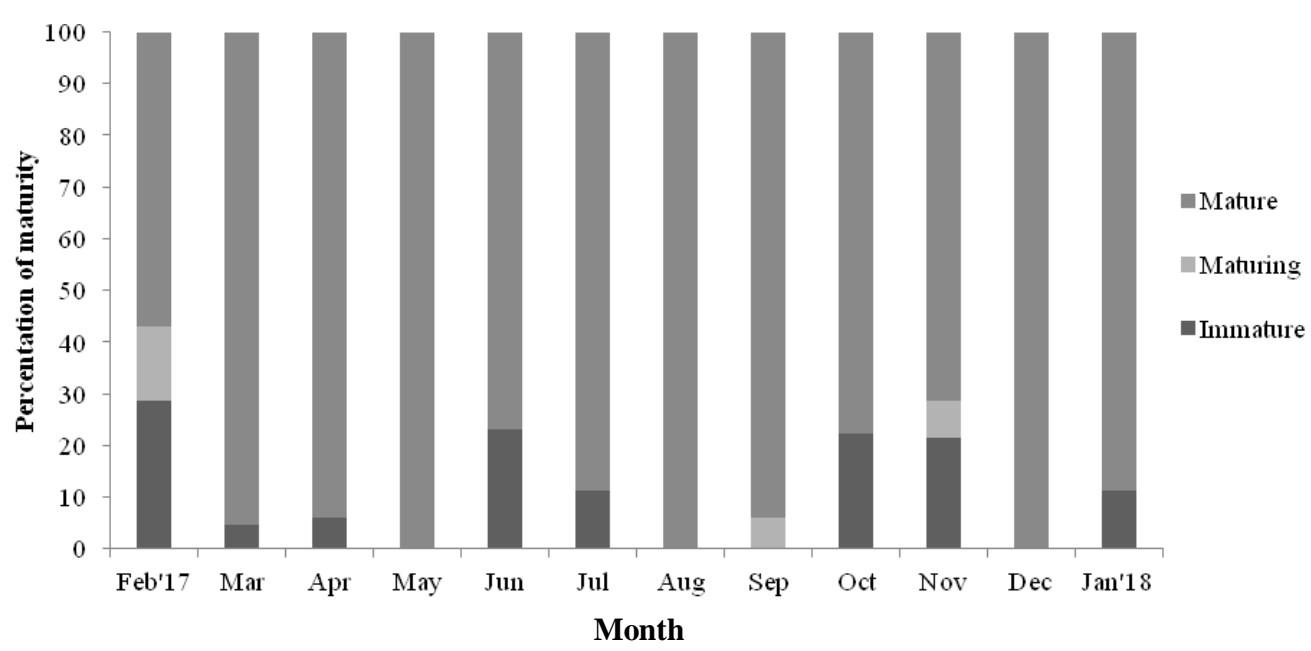

Figure 10. Percentage of maturity for male Atelomycterus marmoratus in the waters of Seribu Islands, Indonesia

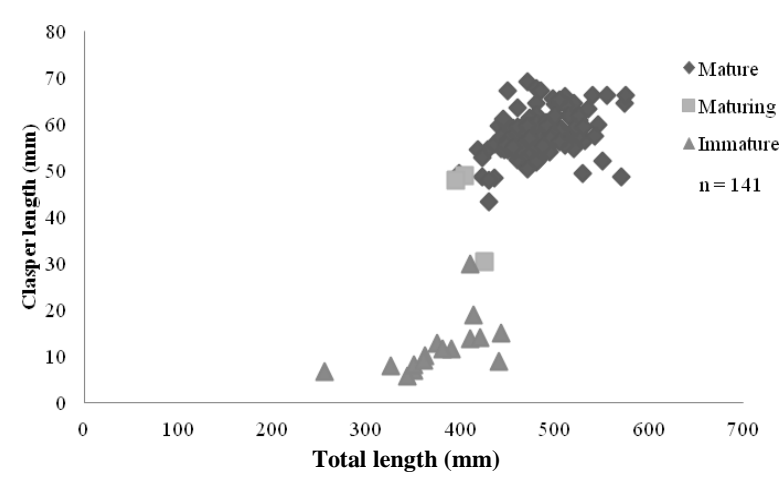

Figure 11. Relationship between total length and clasper length of male Atelomycterus marmoratus in the waters of Seribu Islands, Indonesia

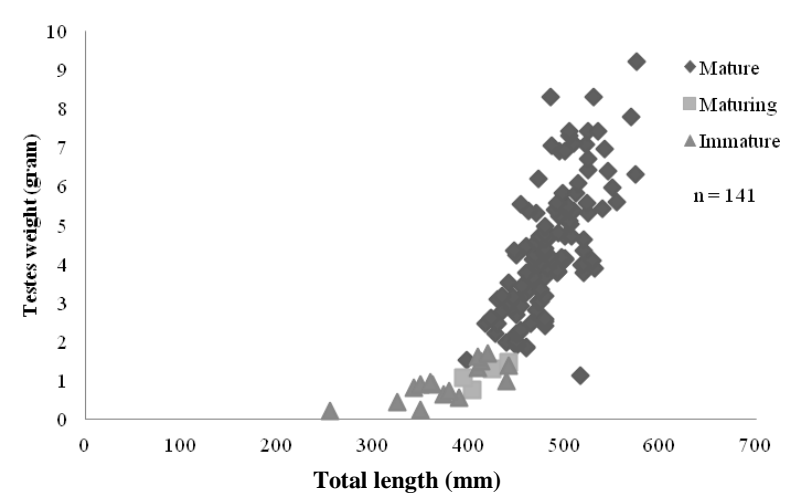

Figure 12. Relationship between total length and testes mass for male Atelomycterus marmoratus in the waters of Seribu Islands, Indonesia

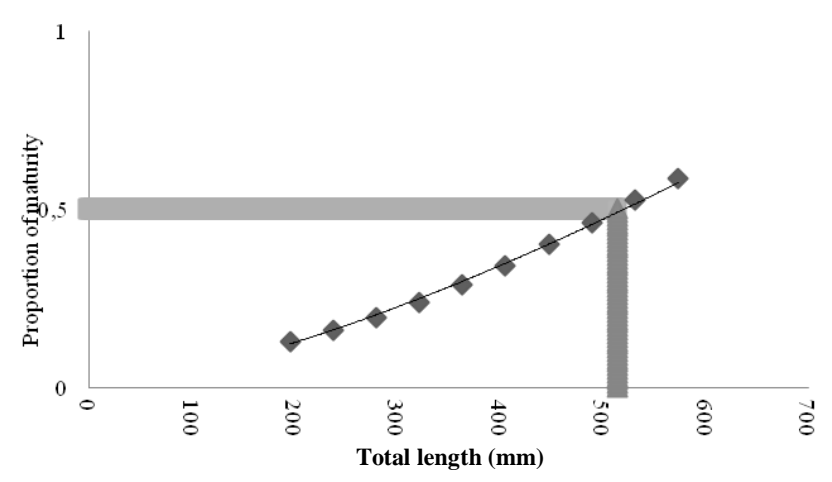

Figure 13. Relationship between the proportion of maturity and total length for male Atelomycterus marmoratus in the waters of Seribu Islands, Indonesia

Figure 13 shows the relationship between the proportion of mature males (Y) in each length interval. The relationship was estimated by an equation $\mathrm{Y}=1 /\left[1+\mathrm{e}^{(3,082-}\right.$ ${ }^{0,006 \mathrm{TL})}$. Based on the equation, the mean size at first maturity for males (when the proportion of maturity at 0.5 ) was $514 \mathrm{~mm}$ TL.

Based on the GSI values, mature females reached a maximum in April, September, and December while mature males were in April, July, and December (Figure 14.A-B). October to March suspected as ovulation season, while September to April was mating season. The ovulation estimation is also supported by many individuals with egg cases in the uteri from October to March, as well as the mean of maximum ovum diameter is large in those months. 

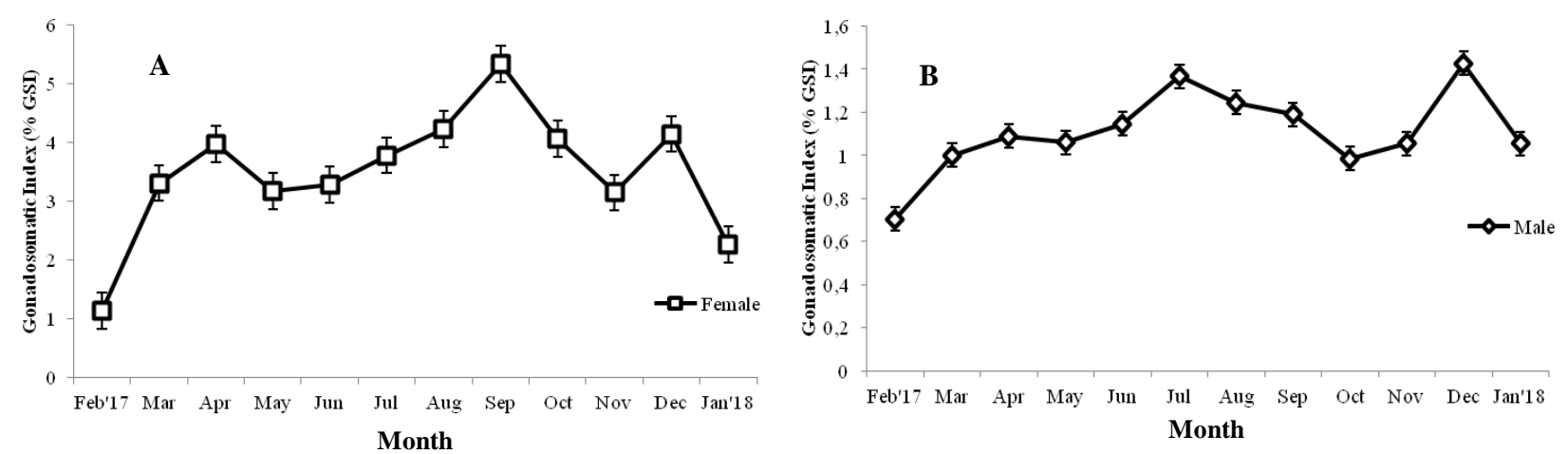

Figure 14. Monthly variation in the mean gonado somatic index (GSI) for male (A) and female (B) Atelomycterus marmoratus in the waters of Seribu Islands, Indonesia

\section{Discussion}

The maximum length of individuals recorded in this study was less than the estimated maximum length of the coral catshark by Compagno and Niem (1998) at $700 \mathrm{~mm}$ TL. Another study from data collection at some landing sites in Bali and Lombok during 2000 to 2006, recorded that the coral catshark ranged from $348-678 \mathrm{~mm}$ TL, with predominant specimens in the 500-699 mm TL interval length (White 2007a). The differences in the mean size of the shark catch can be caused by size-specific gear selectivity (Chen and Liu 2006) or maybe an indicator of the high fishing pressure in our study area. The reduction in size and biomass of fishes are common indicators of the impact of human presence and fishing pressure, especially in the coral reef community (Robinson et al. 2016).

The maximum total length of female coral catsharks was larger than males in this study. This finding was similar to the study of this species by White (2007a) and also to other elasmobranch species in Indonesian waters (Fahmi and Sumadhidarga 2007; White 2007b; Fahmi and Sentosa 2018). Females of most shark species generally reach a larger size than males, attain maturity at greater age and tend to live longer than males (Compagno 1984; Cortes 2000). However, Ebert et al. (2006) stated that this condition might be different for several oviparous sharks. In their study, males of some catshark species attained maximum total length at a greater size than males.

The sex ratio between females and males of the coral catsharks in Seribu Islands waters were not significantly different or in equal condition. However, the monthly sex ratio showed differences in April and September. In general, male coral catsharks were predominant than females. We estimate that in the mating season, male coral catsharks stay in the fishing ground because commonly female can copulate with more than one male coral catshark in each spawning season. So far, studies on reproduction strategy and behavior for coral catshark are still lacking. However, we suspect that there is no sex segregation and geographical or temporal migrations in their life cycle because this species mostly live sedentarily and associated with a coral reef. This is contrary to the condition found in Scyliorhinus canicula by Ellis and
Shackley (1997), they stated clearly that the difference in the sex ratio was a result of unisexual shoaling, i.e., behavioral segregation.

The value of sex ratio for each species and each area can be different, Ebert et al. (2006) suggested that four southern Africa catshark species (Apristurus saldanha, Apristurus sp., Galeus polli, and Scyliorhinus capensis) did not show any significant difference between males and females, nevertheless the sex ratio of Apristurus microps significantly different from the expected 1:1 ratio. Chiloscyllium plagiosum of Northern Waters of Taiwan and Scyliorhinus canicula from Bristol Channel, UK as well as from the Irish and the Celtic Sea also had similar result, which females were predominant than males (Ellis and Shackley 1997; Ivory et al. 2004; Chen and Liu 2006). Meanwhile, Fahmi and Sumadiharga (2007) noted that the proportions between males and females of Carcharhinus brevipinna and C. falciformis from Western Indonesia were about equal, whereas for C. sorrah and Sphyrna lewini were significantly different. Those differences may be related to depth distribution, geography, habitat, season, temperature (Compagno et al. 1991) or simply a sampling artifact (Ebert et al. 2006).

The length and mass relationships for female and male coral catsharks were relatively similar to the category of negatively allometric. It means that the length grows faster than the mass. However, the growth rate is still not known because it has not yet been determined for their ages, whether through the vertebrae or the length approach.

Most members of the family Scyliorhinidae are oviparous species, including coral catshark Ateleomycterus marmoratus. This species has asymmetrical ovaries, which the left ovary is different from the right one. The left ovary is small or absent, and only right ovary can develop until producing the oocytes. Nevertheless, the function of both left and right uteri are normal and can keep the egg cases. Coral catshark is considered as single oviparity, with only a single egg case deposited for each uterus at a time. This condition similar to other oviparous sharks such as Scyliorhinus canicula, S. capensis, Apristurus microps, A. saldanha and Chiloscyllium plagiosum (Ellis and Shackley 1997; Chen and Liu 2006; Ebert et al. 2006). According to 
Chen and Liu (2006), the difference in mass between both ovaries was likely caused by the amount of stroma tissue differs among left and right ovaries, not the differences in number or size of ovarian follicles.

The study on egg cases of the coral catshark had been done by Bor et al. (2003). They noted that egg cases of the three Atelomycterus species were very similar, with two constrictions and short tendrils. However, there was a difference in relative width among the three of them. Ebert et al. (2006) explained that variations in egg case structure among species indicate which they had a different habitat to deposit their egg cases. Hövel et al. (2010) added short tendrils were used to anchor the egg cases to the bottom. His experiments showed that eggs of coral catshark were deposited on the lower level bottom ground of the public exhibit tank. After egg deposition, embryonic development occurred, and juvenile hatched after 4-6 months. The observation by Hövel et al. (2010) also found that the freshly hatched coral catshark ranged from 100 to $130 \mathrm{~mm}$ TL.

The estimation of size at first maturity of male coral catsharks from Seribu Islands was slightly smaller compared to the previous study by White (2007a). The size of predominant and the maximum length of specimens from Bali and Lombok (White 2007a) were larger than the population in the Seribu Islands. Environmental condition and fishing pressure may be influential factors for the differences. On the other hand, White (2007a) did not estimate the size at first maturity for female specimens, but White et al. (2006) estimated at around $490 \mathrm{~mm}$ TL. That estimate was still in the range size of our estimation for female's size at first maturity.

Our estimations on the condition of $50 \%$ population mature $(\mathrm{Lm})$ for both males and females were larger than previous studies (White et al. 2006; White 2007a), but were still in the range of the estimation for size at maturity of this species in the Western Central Pacific region (Compagno and Niem 1998). They estimated male coral catsharks get their maturity in size 470-620 mm TL and females in size $490-570 \mathrm{~mm}$ TL. Also, our estimations were met with the estimated Lm values for Elasmobranchs suggested by Holden and Raitt (1974), which were between 0.6 and 0.9 from the maximum total length (Lmax). Our study showed that the ratio between Lm and Lmax for males and females were 0.89 and 0.95 , respectively. For comparison, the proportion between Lm and Lmax for five catshark species in Southern Africa were recorded between 0.68 and 0.91 (Ebert et al. 2006).

Correct estimation of the Lm value is meaningful for the proper fish stock management (Fontoura et al. 2009). Concerning the catshark fishery in Seribu Islands waters, the record of about $75 \%$ of total mature individuals collected during our study may give a good indication for the coral catshark fishery in this area. It means that the fishermen commonly catch the coral catsharks in size larger than the Lm value. So that, coral catsharks were allowed to grow up and reproduce.

Our study also found that male coral catsharks mature at smaller size than females. Our finding was slightly different from a study by Ebert et al. (2006) on four catshark species in African waters. However, other studies on catsharks in Indonesia supported our finding (White et al. 2006; White 2007a) and also one other species of catshark from southern Africa, G. polli (Ebert et al. 2006). It appears to be a common characteristic among oviparous catsharks that males are reaching maturity at about the same size or larger than females (Compagno 1984).

The spawning season of coral catshark was estimated by the gonadosomatic index (GSI). However, this approach has a specific problem because the GSI values depend on the sample size, sampling site, and sampling period (Fontoura et al. 2009). Our suggestion on the ovulation and mating seasons showed that there is reproduction isolation or time lag between mating and ovulation for coral catshark. However, further examination is needed for ensuring this hypothesis. More information on behavior and strategy reproduction of the coral catshark are also required for determining the best fisheries management of this species.

\section{ACKNOWLEDGMENTS}

A special thanks to Nurul Fitriya, Johan Picasouw and Asep Rasyidin of Research Centre for Oceanography, Indonesian Institute of Sciences (RCO, LIPI), Jakarta for their assistance in the field and laboratory. This project was funded by the RCO, LIPI financial year 2017.

\section{REFERENCES}

Bor PHF, van Oijen MJP, Magenta C. 2003. The egg capsule of the coral cat shark, Atelomycterus marmoratus (Bennett, 1830) (Chondrichthyes: Scyliorhinidae). Zool Med Leiden 77(19): 325-330.

Chen WK, Liu KM. 2006. Reproductive biology of white-spotted bamboo shark Chiloscyllium plagiosum in northern waters off Taiwan. Fisher Sci 72 (6): 1215-1224.

Compagno LJV. 1984. FAO species catalogue. Sharks of the world. An annotated and illustrated catalogue of sharks species known to date. Part 1: Hexancathiformes to Lamniformes. FAO, Rome.

Compagno LJV. 1988. Sharks of the Order Carcharhiniformes. Princeton University Press, New Jersey.

Compagno LJV, Ebert DA, Cowley PD. 1991. Distribution of offshore demersal cartilaginous fishes (class Chondrichthyes) of the west coast of southern Africa, with notes on their systematics. South African J Mar Sci 11: 43-139.

Compagno LJV, Niem VH. 1998. Catsharks. In Carpenter KE, Niem VH (eds) Species identification guide for fishery purposes. The living marine resources of the western central Pacific. Cephalopods, crustaceans, holothurians and sharks. FAO, Rome.

Cortes, E. 2000. Life history patterns and correlations in sharks. Reviews in Fisheries Science 8: 299-344.

Compagno LJV, Dando M, Fowler SL. 2005. Sharks of the world. Princeton University Press, New Jersey:

Ebert DA, Comagno LJV, Cowley PD. 2006. Reproductive biology of catsharks (Chondrichthyes: Scyliorhinidae) off the west coast of southern Africa. ICES J Mar Sci 63: 1053-1065.

Ellis JR, Shackley SE. 1997. The reproductive biology of Scyliorhinus canicula in the Bristol Channel, U.K. J Fish Biol 51: 361-372.

Fahmi, Sumadhiharga K. 2007. Size, sex, and length at maturity four common sharks caught from western Indonesia. Mar Res Indon 32 (1): 7-19.

Fahmi. 2016. Potensi hiu dan pari sebagai komoditi ikan hias dan aspek konservasinya; Proceeding of National Symposium on Ornament Fish, Depok. [Indonesian] 
Fahmi, White WT. 2015. Atelomycterus erdmanni, a new species of catshark (Scyliorhinidae: Carcharhiniformes) from Indonesia. J Ocean Sci Found 14: 14-27.

Fahmi, Sentosa AA. 2017. Biology and fisheries aspects of western longnose spurdog, Squalus edmundsi from the Eastern Indian Ocean, Indonesia. Biodiversitas 18 (4): 1714-1722.

Fontoura NF, Braun AS, Milani PCC. 2009. Estimating size at first maturity $\left(\mathrm{L}_{50}\right)$ from Gonadosomatic Index (GSI) data. Neotrop Ichthyol 7(2): 217-222.

Gay LR. 1996. Educational research: competencies for analysis and application. Prentice-Hall, New Jersey.

Holden MJ, Raitt DFS. 1974. Manual of fisheries science part 2-methods of resource investigation and their application. FAO, Rome.

Hövel A, Ommer S, Ziegler T. 2010. Keeping and breeding of the coral catshark (Atelomycterus marmoratus) at the aquarium of the cologne zoo. Zool Garten NF. 79: 243-253.

Ivory P, Jeal F, Nolan CP. 2004. Age Determination, Growth and Reproduction in the Lesser-spotted Dogfish, Scyliothinus canicula (L.). J. Northw. Atl Fish Sci 35: 89-106.

King M. 1995. Fisheries biology assessment and management. Fishing News Book, Oxford.

Morey G, Moranta J, Massuti E, Grau A, Linde M, Riera F, Morales-Nin B. 2003. Weight-length relationships of littoral to lower slope fishes from the Western Mediterranean. Fisher Resour 62: 89-96.

Pratt HL.1988. Elasmobranch Gonad Structure: A Description and Survey. Copeia (3): 719-729.
Ricker WE. 1973. Linear regression in fisheries research. J Fisheries Research Board of Canada 30: 409-434.

Robinson JPW, Williams ID, Edwards AM, McPherson J, Yeager L, Vigliola L, Brainard R, Baum JK. 2016. Fishing degrades size structure of coral reef fish communities. Glo Ch Biol 23(3): 1-14.

Stehmann MFW.2002. Proposal of a maturity stages scale for oviparous and viviparous cartilaginous fishes (Pisces, Chondrichthyes). Arch Fisher Mar Res 50 (1): 23-48.

White WT. 2003. Atelomycterus marmoratus. The IUCN Red List of Threatened Species 2003: e.T41730A10550175. SSG Australia \& Oceania Regional Workshop, March 2003. DOI: 10.2305/IUCN.UK.2003.RLTS.T41730A10550175.en. [22 January 2019].

White WT, Last PR, Dharmadi. 2005. Description of a new species of catshark, Atelomycterus baliensis (Carcharhiniformes: Scyliorhinidae) from eastern Indonesia. Cybium 29(1): 33-40.

White WT, Last PR, Stevens JD, Yearsley GK, Fahmi, Dharmadi.2006. Economically important sharks and rays of Indonesia. ACIAR, Canberra.

White WT. 2007a. Aspects of the biology of carcharhiniform sharks in Indonesian waters. J Mar Biol Assoc UK 87: 1269-1276.

White WT. 2007b. Biological observations on lamnoid sharks (Lamniformes) caught by fisheries in eastern Indonesia. J Mar Biol Assoc UK 87: 781-788. 